\title{
ASSESSMENT OF ROTARY IMPELLER EFFICIENCY BY PHYSICAL MODELLING OF AN ALUMINUM REFINING PROCESS
}

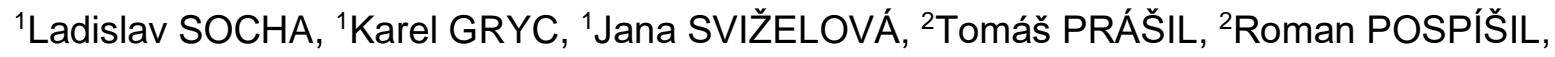 \\ ${ }^{2}$ Martin GRÁF \\ ${ }^{1}$ Institute of Technology and Business in České Budějovice, České Budějovice, Czech Republic, EU, \\ socha@mail.vstecb.cz, gryc@mail.vstecb.cz, svizelova@mail.vstecb.cz \\ ${ }^{2}$ MOTOR JIKOV Slévárna (Foundry) a.s., Die-casting Division, České Budëjovice, Czech Republic, EU, \\ TPrasil@migroup.cz, RPospisil@misl.cz, MGraf@misl.cz
}

https://doi.org/10.37904/metal.2021.4258

\begin{abstract}
This paper aims to assess the efficiency of graphite impellers type A and B, investigated in the study of an aluminum refinement process using a physical model of the foundry degassing unit. This model operates in the laboratories of the Environmental Research Department of the Institute of Technology and Business in České Budějovice. For this purpose, a series of experiments were performed for each impeller type with different process parameters. The efficiency was evaluated based on oxygen concentration in water reached after $180 \mathrm{~s}$ of the refining process. Impeller $\mathrm{A}$ was found to achieve lower oxygen concentrations in water after $180 \mathrm{~s}$ and was therefore considered to be more efficient. The conclusions will be further verified under operating conditions of the Die-casting Division of MOTOR JIKOV Slévárna (Foundry) a.s.
\end{abstract}

Keywords: Aluminum, physical modelling, refinement process, FDU, impeller design

\section{INTRODUCTION}

Aluminum alloys contain numerous impurities that affect the properties of finished castings. In particular, hydrogen and non-metal inclusions should be mentioned among these phases. Hydrogen is characterised by a very negative impact on aluminum casting properties. Moisture contained in raw materials of the charge and other materials that come in contact with the molten mass is usually the source of hydrogen [1].

Thanks to its high affinity to oxygen, aluminum reacts with moisture; elementary hydrogen is thereby released and becomes dissolved in the metal [1]. The adverse effect of hydrogen is caused by its different solubility in the liquid and solid phase. This is demonstrated by temperature dependence of hydrogen solubility in aluminum and its alloys illustrated in Figure 1. As can be seen, hydrogen solubility in the liquid phase is relatively high. However, as the temperature decreases, its solubility is considerably reduced. A similar trend can also be observedin the case of hydrogen solubility in aluminum alloys [2]. In the process of solidification, hydrogen becomes separated from the metal and its atoms bond to form gaseous $\mathrm{H}_{2}$ molecules which results in casting porosity [3].

At a specific temperature, hydrogen solubility also depends on its partial pressure in the surrounding atmosphere. This dependence is described

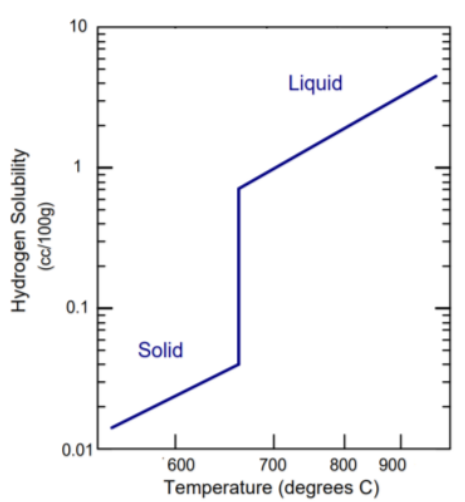

Figure 1 Hydrogen solubility in molten aluminum $[1,5]$ by theSieverts law, the principle of which is used in molten aluminum degassing [1, 4]. In practice, this means 
that dissolved hydrogen diffuses into the bubbles of a refining gas and is transported in the gas outside the molten aluminum.

This principle is used by the FDU (Foundry Degassing Unit, see Figure 2) refining system [6] whose scheme is illustrated in Figure 3. The system is composed of a graphite impeller and a hollow shaft used to introduce an inert gas into the molten mass. Usually, a baffle is added to these components. The impeller disperses inert gas into small bubbles and ensures their uniform distribution throughout the refining pan. Generally, the smaller the bubble sizes, the larger the overall specific surface of the phase interface between the bubble and the molten mass through which hydrogen diffuses into the inert gas $[5,6]$. Additionally, smaller bubbles have a longer retention time in the molten mass, thereby providing more time for hydrogen diffusion into the bubble [7]. Moreover, the impeller induces turbulent flow which supports the hydrogen removal kinetics [4].
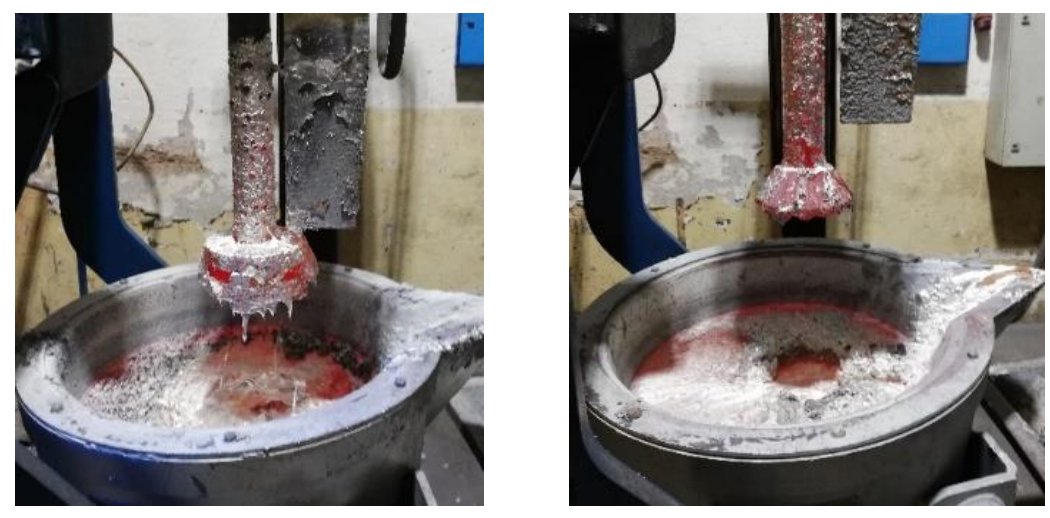

Figure 2 Foundry Degassing Unit (FDU) during melt processing for die casting

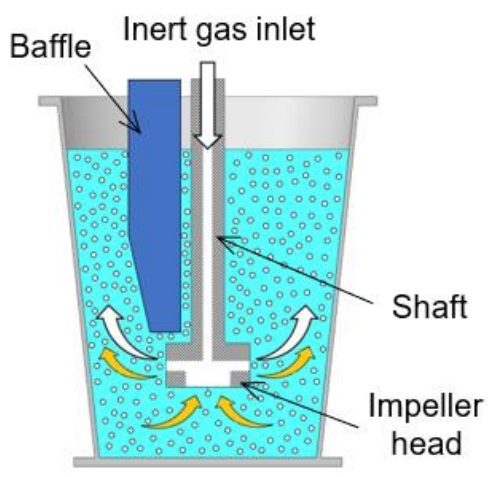

Figure 3 Principle of refinement process by the FDU unit [6]

Hydrogen removal efficiency is affected by many factors including the alloy type, melting temperature, initial hydrogen content in the molten mass, type and amount of the refining gas, but also the FDU unit parameters such as the impeller rotation frequency, the working height, etc. [7-11]. However, the shape of the impeller itself also has a significant impact on degassing efficiency as previously demonstrated by a number of studies, e.g. [12-15].

The objective of this study was to compare refining efficiency of molten aluminum at the FDU unit using two graphite impellers of different geometries. The research was performed using physical modelling at laboratories of the Environmental Research Department of the Institute of Technology and Business in České Budějovice. The purpose of physical modelling was to sufficiently simulate the given process in order to assess its intensity and subsequently, to apply the learned information in operating conditions. For this purpose, experiments were performed using two impeller types, A and B, and degassing intensity was monitored. An appropriate impeller type for testing in operating conditions will be recommended based on the results.

\section{DESCRIPTION OF PHYSICAL MODEL AND EXPERIMENTAL METHODOLOGY}

A physical model of the refining system was constructed for the purpose of physical modelling of aluminum alloy degassing (see Figure 4). The physical model was constructed according to the FDU unit used at MOTOR JIKOV Slévárna (Foundry) a.s. Essential components of the system include a plexiglass vessel (refining pan model), graphite impeller, baffle and optic probes to measure oxygen concentration in water. The impeller is propelled by an electric motor with speed regulation. In order to respect geometric conformity of the model and the work, the model vessel was manufactured in the 1:1 ratio with respect to the operating pan. The tested impellers and the baffle (see Figure 5) are standard components used in operating conditions. 

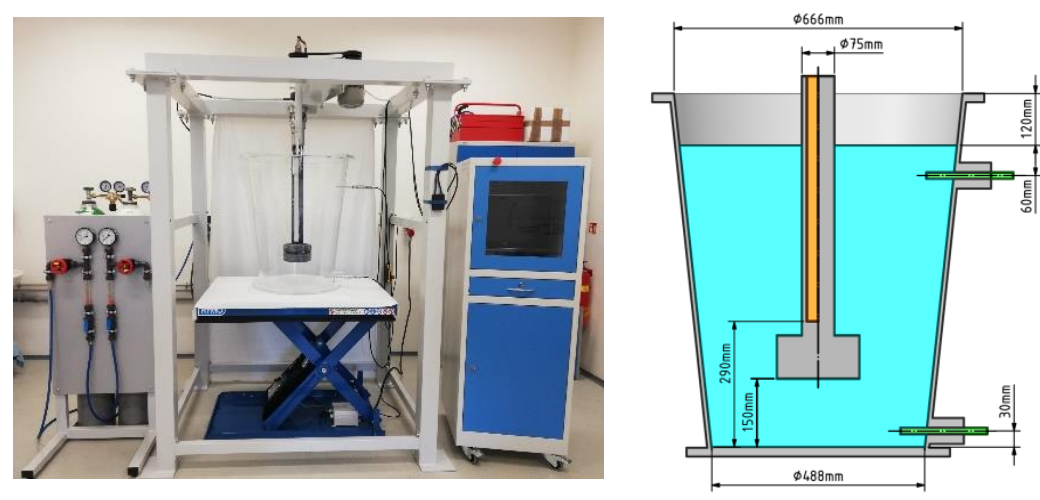

Figure 4 Illustration of the physical model, components layout and base dimensions of the model assembly
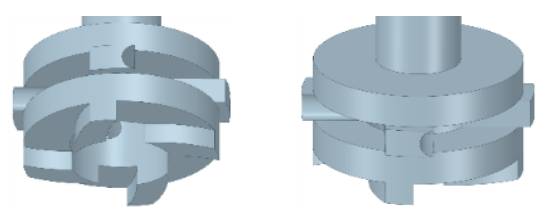

a) Impeller $A$
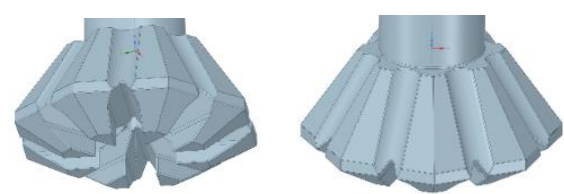

b) Impeller $B$

Figure 5 Impeller design

The principle of physical modelling was aimed at capturing molten mass degassing intensity and analysing how the harmful gas content decreases with various parameter values under laboratory conditions. For this purpose, it was necessary to choose appropriate media that would preserve dynamic similarity between the model and the actual work. Therefore, molten aluminum was replaced with water and the hydrogen to be removed was replaced with oxygen. To give a better idea, basic characteristics of molten aluminum and model media are presented in Table 1.

Table 1 Properties of molten aluminum and model media

\begin{tabular}{|l|c|c|c|}
\hline \multicolumn{1}{|c|}{ Parameter } & Aluminum & Water & Oxygen \\
\hline Temperature $\left({ }^{\circ} \mathrm{C}\right)$ & 750 & 20 & 20 \\
\hline Density $\left(\mathrm{kg} \cdot \mathrm{m}^{-3}\right)$ & 2345 & 998.2 & 1.299 \\
\hline Dynamic viscosity $\left(\mathrm{kg} \cdot \mathrm{m}^{-1} \cdot \mathrm{s}^{-1}\right)$ & $1.200 \cdot 10^{-3}$ & $1.003 \cdot 10^{-3}$ & $0.019 \cdot 10^{-3}$ \\
\hline Kinematic viscosity $\left(\mathrm{m}^{2} \cdot \mathrm{s}^{-1}\right)$ & $0.51 \cdot 10^{-6}$ & $1.01 \cdot 10^{-6}$ & $14.77 \cdot 10^{-6}$ \\
\hline
\end{tabular}

Table 2 presents operating conditions of the molten aluminum refining process; these conditions were used as a basis to determine the physical modelling conditions for the studied impeller types. Based on these conditions, laboratory experiments using the physical model were defined and carried out in order to describe the effects of key refining process variables on molten mass degassing intensity. The actual parameters and conditions of individual experiments using the FDU physical model were designed in cooperation with technologists of the Die-casting Division of MOTOR JIKOV Slévárna (Foundry) a.s. Basic parameters taken into account when defining the model variants included: impeller type, working height, number of baffles, rotation frequency, and the inert gas (Ar) flow rate.

Table 1 Definitions of model parameters

\begin{tabular}{|l|c|c|c|c|}
\hline \multirow{2}{*}{\multicolumn{1}{|c|}{ Parameter }} & \multicolumn{2}{c|}{ Impeller A } & \multicolumn{2}{c|}{ Impeller B } \\
\cline { 2 - 5 } & $\begin{array}{c}\text { Operating } \\
\text { conditions }\end{array}$ & $\begin{array}{c}\text { Physical } \\
\text { model }\end{array}$ & $\begin{array}{c}\text { Operating } \\
\text { conditions }\end{array}$ & $\begin{array}{c}\text { Physical } \\
\text { model }\end{array}$ \\
\hline Working height of impeller $(\mathrm{mm})$ & 200 & $150^{*}$ & 150 & 150 \\
\hline Number of baffles $(\mathrm{pc})$ & 1 & 1 & 1 & 1 \\
\hline Refinement time $(\mathrm{s})$ & 180 & 180 & 180 & 180 \\
\hline Rotation frequency $(\mathrm{rpm})$ & 350 & 325 to 400 & 375 & 325 to 400 \\
\hline Inert gas type $(\times \times \times)$ & Nitrogen & Argon & Nitrogen & Argon \\
\hline Inert gas flow rate $\left(\mathrm{Nl} \cdot \mathrm{min}^{-1}\right)$ & 17 & 13 to 19 & 15 & 13 to 19 \\
\hline
\end{tabular}

\footnotetext{
* Included to allow efficiency comparison with the other impeller type
} 
The presented research focused on describing the effect of impeller shape on degassing intensity. Two impeller types were chosen for this purpose (see Figure 5). The efficiency of each impeller was verified under different parameter settings, and therefore variants of experiments with different rotation frequencies and inert gas flow rates were defined for each. In order to verify the impact of the impeller shape on degassing intensity, 16 experiment variants were carried out for each impeller type, whose parameters are presented in Table 3.

Table 3 Definitions of modelled variants - impellers A and B

\begin{tabular}{|c|c|c|c|c|c|c|c|c|c|c|c|c|c|c|c|c|}
\hline Working height $(\mathrm{mm})$ & \multicolumn{16}{|c|}{150} \\
\hline Baffles (pc) & \multicolumn{16}{|c|}{1} \\
\hline Rotation frequency (rpm) & \multicolumn{4}{|c|}{325} & \multicolumn{4}{|c|}{350} & \multicolumn{4}{|c|}{375} & \multicolumn{4}{|c|}{400} \\
\hline Argon flow rate $\left(\mathrm{N} l \cdot \mathrm{min}^{-1}\right)$ & 13 & 15 & 17 & 19 & 13 & 15 & 17 & 19 & 13 & 15 & 17 & 19 & 13 & 15 & 17 & 19 \\
\hline
\end{tabular}

\section{RESULTS AND DISCUSSION}

Experiments using the physical model provided time dependence of oxygen concentration decrease in water, illustrated in Figure 6 and Figure 7. Considering the quality of the results, only selected graphs are provided below, demonstrating the effect of changes in impeller rotation frequency and inert gas flow rate. To give an idea, Figure 6 and Figure 7 show concentration curves measured at 350 and 400 rpm and various argon flow rates for both impeller types. Clearly, the process of oxygen removal from water is accelerated as the flow rate of argon increases. An increase of rotation frequency of the impeller had a similar effect, as well.
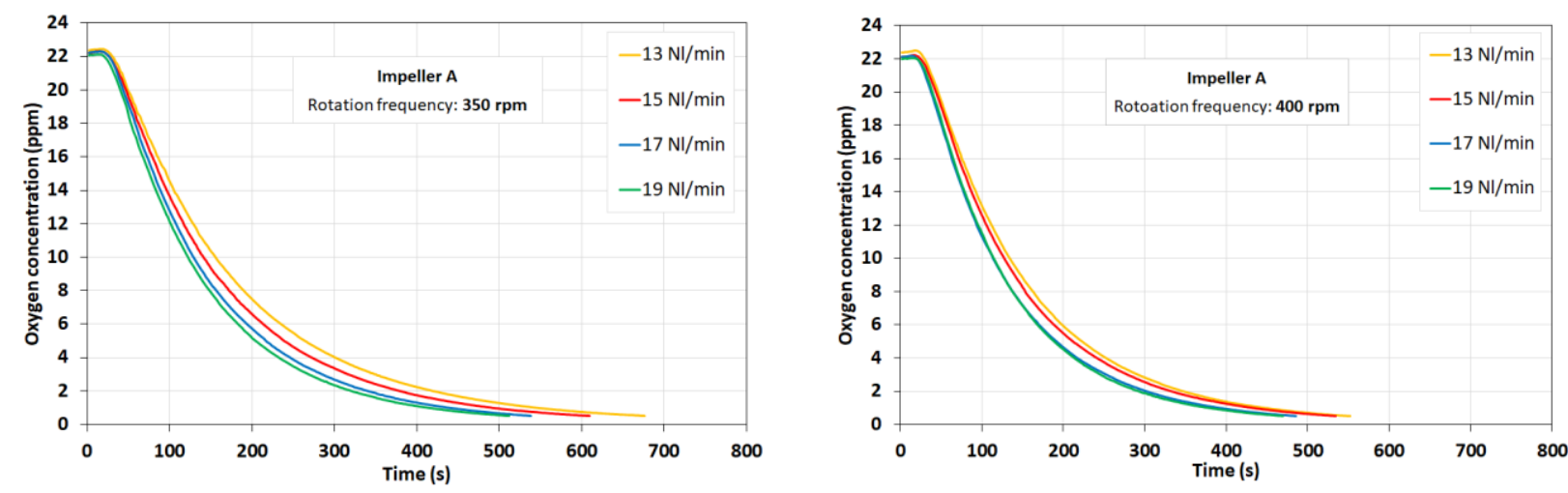

Figure 6 Concentration curves measured on the physical model - impeller A

- change of argon flow rate and rotation frequency
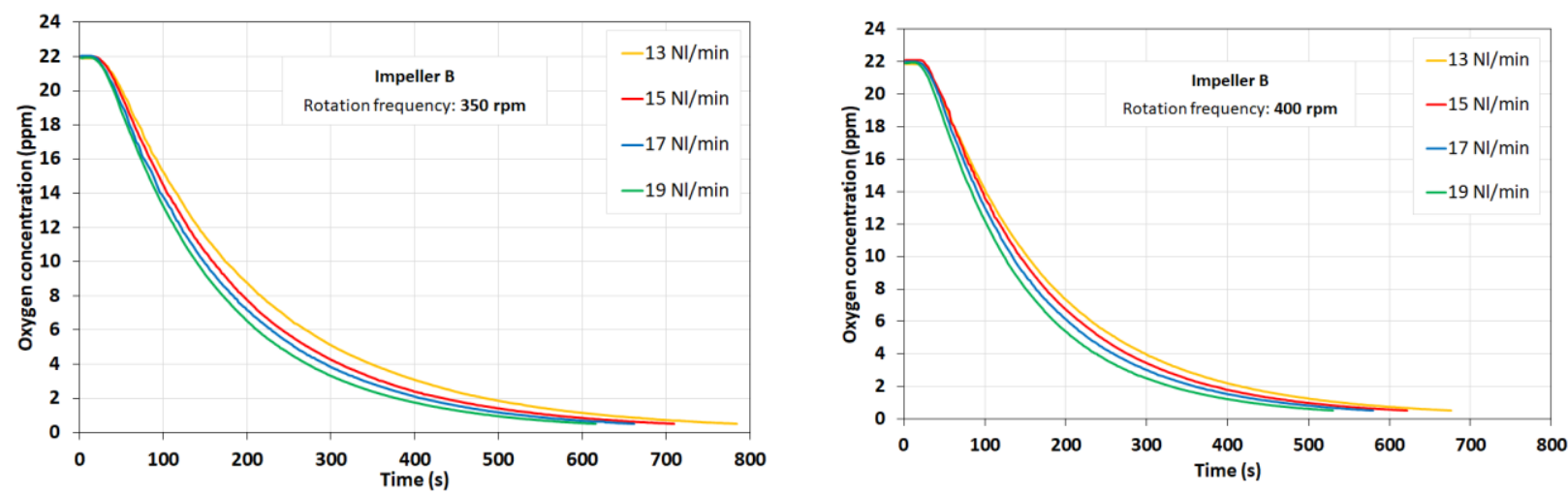

Figure 7 Concentration curves measured on the physical model - impeller B - change of argon flow rate and rotation frequency 
The curves above were used as the basis to assess impeller efficiency. Under operating conditions, the duration of molten aluminum refining is $180 \mathrm{~s}$. Thus in accordance with operating conditions, the physical modelling results were analysed after $180 \mathrm{~s}$ of degassing (as indicated in Figure 6 and Figure 7). The results are presented in Figure 8, which shows oxygen concentration values in water after $180 \mathrm{~s}$ of degassing under various conditions. As follows from the results, of the two studied impellers, impeller A shows the lowest oxygen concentration values in water after $180 \mathrm{~s}$ under any combination of the defined conditions. Thus it can be stated that impeller A provides higher degassing efficiency compared to impeller $\mathrm{B}$.

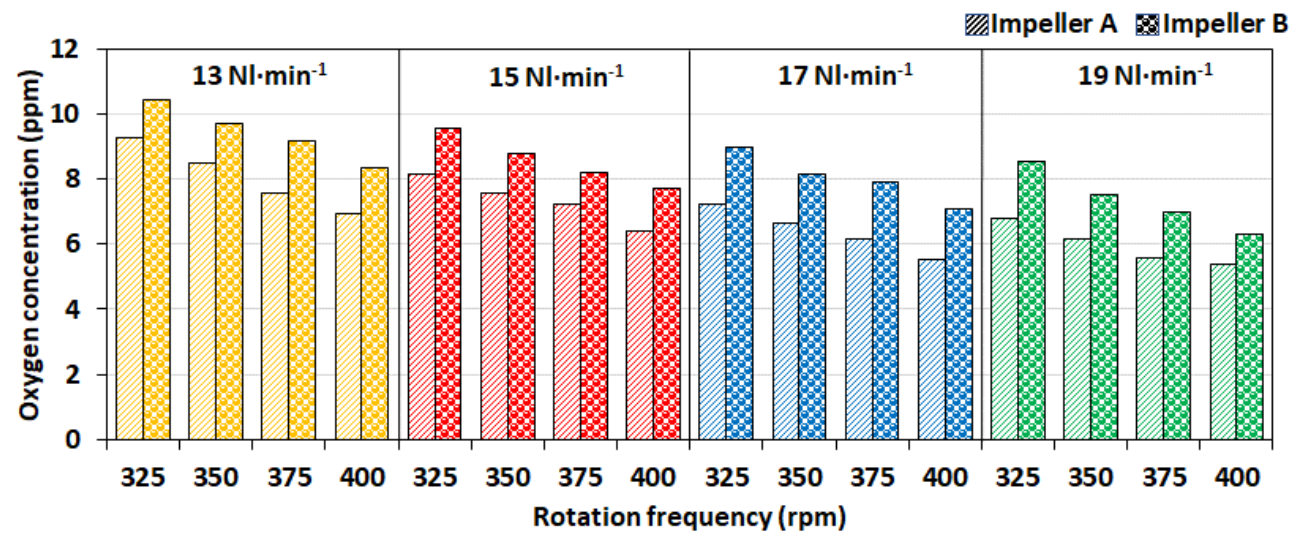

Figure 8 Comparison of measured values of oxygen concentration after $180 \mathrm{~s}$ of deoxygenation for impeller $\mathrm{A}$ and $\mathrm{B}$

\section{CONCLUSIONS}

A physical model of the FDU refining unit was constructed for the model-based study of molten aluminum degassing. The model was used for experiments in order to compare various types of graphite impellers in terms of their efficiency of oxygen removal from water. The defined conclusions can be summarized as follows:

$\checkmark \quad$ Experiment variants were defined for each of the impeller types $A$ and $B$ to determine degassing efficiency. Impeller efficiency was mapped in a wider range of operating parameters. Impeller rotation frequency was defined in the range of 325 to 400 rpmand argon flow rate in the range of 13 to $19 \mathrm{Nl} \cdot \mathrm{min}^{-1}$.

$\checkmark \quad$ Evaluation of the results revealed an impact on impeller rotation frequency and argon flow rate on degassing efficiency. While increasing rotation frequency under constant argon flow rate, oxygen concentrations in water achieved after $180 \mathrm{~s}$ of degassing were decreasing.

$\checkmark \quad$ The impact of argon flow rate was similar. With increased argon flow rate under constant rotation frequency, lower oxygen concentrations in water were achieved after $180 \mathrm{~s}$ of degassing in the physical model.

$\checkmark \quad$ In all tested parameter combinations, impeller $A$ achieved lower oxygen concentrations in water after 180 s of degassing in the physical model. Thus it can be stated that impeller $A$ provides a higher degassing efficiency compared to impeller $B$.

In further research stages, the results will be tested and verified in the FDU operating unit at MOTOR JIKOV Slévárna (Foundry) a.s.

\section{ACKNOWLEDGEMENTS}

The paper was prepared under the support of the Technology Agency of the Czech Republic within the scope of the EPSILON programme, as part of projects Reg. No. TH04010449 "Research and development of refining technologies for increasing of quality of aluminum alloys for high-performance quality castings". 


\section{REFERENCES}

[1] SIGWORTH, G.K., WILLIAMS, E.M., CHESONIS, D.C. Gas fluxing of molten aluminum: An overview. DEYOUNG, D.H. Light Metals 2008. New Orleans, 2008. ISBN 978-0-87339-710-0.

[2] BOLIBRUCHOVÁ, D., TILLOVÁ, E. Casting alloys Al-Si. Žilina: Žilinská univerzita, 2005. ISBN 80-8070-485-6.

[3] VOJTĚCH, D. Metallic materials. 1. Ed. Prague: University of Chemistry and Technology Prague, 2006. ISBN 807080-600-1.

[4] MYSLIVEC, T. Physico-chemical bases of steel industry. Prague: SNTL, 1971.

[5] MICHNA, Š, LUKÁČ, I. et al. Aluminum materials and technologies from A to Z. Prešov: Adin s.r.o., 2007. ISBN 80-890-4188-4.

[6] FDU Foundry Degassing Unit. Vesuvius [online]. [viewed: 2021-5-5]. Available from: https://www.vesuvius.com/content/dam/vesuvius/corporate/Our-solutions/our-solutions-masterenglish/foundry/non-ferrous-foundry/melt-treatment/brochures/FDU-e.pdf.downloadasset.pdf

[7] WARKE, V.S., TRYGGVASON, G., MAKHLOUF, M.M. Mathematical modeling and computer simulation of molten metal cleansing by the rotating impeller degasser: Part I. Fluid flow. Journal of Materials Processing Technology. [online]. 2005, vol. 168, no. 1, pp. 112-118. Available from: https://doi.org/10.1016/j.jmatprotec.2004.10.017.

[8] MERDER, T., SATERNUS, M., WARZECHA, P. Possibilities of 3D model application in the process of aluminum refining in the unit with rotary impeller. Archives of Metallurgy and Materials. [online]. 2014, vol. 59, no. 2, pp. 789794. Available from: https://doi.org/10.2478/amm-2014-0134.

[9] LICHÝ, P., BAJEROVÁ, M., KROUPOVÁ, I., OBZINA, T. Refining aluminum-alloy melts with graphite rotors. Materiali in Technologije. [online]. 2020, vol. 54, no. 2, pp. 263-265. ISSN 1580-2949. Available from: https://doi.org/10.17222/mit.2019.147.

[10] MICHALEK, K., TKADLECKOVA, M., SOCHA, L., GRYC, K., SATERNUS, M., PIEPRZYCA, J., MERDER, T. Physical modelling of degassing process by blowing of inert gas. Archives of Metallurgy and Materials. [online]. 2018, vol. 63, no. 2, pp. 987-992. Available from: https://doi.org/10.24425/122432. ISSN 1733-3490.

[11] SATERNUS, M., BOTOR, J. Refining process of aluminum conducted in continuous reactor - physical model. Archives of Metallurgy and Materials. 2010, vol. 55, no. 2, pp. 463-475.

[12] HERNÁNDEZ-HERNÁNDEZ, M., CAMACHO-MARTíNEZ, J.L., GONZÁLEZ-RIVERA, C., RAMÍREZ-ARGÁEZ, M.A. Impeller design assisted by physical modeling and pilot plant trials. Journal of Materials Processing Technology. [online]. 2016, vol. 236, pp. 1-8. ISSN 09240136. Available from: https://doi.org/10.1016/i.jmatprotec.2016.04.031

[13] ABREU-LÓPEZ, D., DUTTA, A., CAMACHO-MARTÍNEZ, J. L., TRÁPAGA-MARTíNEZ, G., RAMíREZ-ARGÁEZ, M.A. Mass transfer study of a batch aluminum degassing ladle with multiple designs of rotating impellers. JOM. [online]. 2018, vol. 70, no. 12, pp. 2958-2967. ISSN 1047-4838. Available from: https://doi.org/10.1007/s11837018-3147-y

[14] MANCILLA, E., CRUZ-MÉNDEZ, W., RAMÍREZ-ARGÁEZ, M. A., GONZÁLEZ-RIVERA, C., ASCANIO, G. Experimental measurements of bubble size distributions in a water model and its influence on the aluminum kinetics degassing. The Canadian Journal of Chemical Engineering. [online]. 2019, vol. 97, no. S1, pp. 17291740. ISSN 0008-4034. Available from: https://doi.org/10.1002/cjce.23432

[15] SVIŽELOVÁ, J., TKADLEČKOVÁ, M., MICHALEK, K., WALEK, J. Development of a monitoring method of hydrogen removal from aluminummelt using numerical modelling. In: METAL 2019: 28th International Conference on Metallurgy and Materials. Ostrava: Tanger, 2019, pp. 1715-1720. ISBN 978-80-87294-92-5. 